\title{
The effect of linseed oil and selenium on the content of fatty acids and some elements in the liver and selected tissues of sheep ${ }^{*}$
}

\author{
M. Czauderna ${ }^{1.3}$, J. Kowalczyk ${ }^{1}$, K.M. Niedźwiedzka', \\ I. Wąsowska' ${ }^{1}$ J.J. Pająk ${ }^{1}$, E. Bulska² and A. Ruszczyńska ${ }^{2}$
}

\author{
'The Kielanowski Institute of Animal Physiology and Nutrition. Polish Acudemy of Sciences \\ 05-110 Jahtonna, Poland \\ 'Warsaw University, Faculty of Chemisty \\ Pasteura 1, 02-093 Warsaw, Poland
}

\begin{abstract}
The effect of selenium (as $\mathrm{Na}_{2} \mathrm{SeO}_{4}$ ) and linseed oil on the mass of $M$. biceps femoris and liver of sheep, as well as on the fatty acid composition and $\mathrm{Se}, \mathrm{Zn}, \mathrm{Fe}, \mathrm{Mg}$ and $\mathrm{Ca}$ levels of $M$. biceps femoris, liver and intermuscular fat was investigated. Twenty male lambs of body weight of $25 \pm 2 \mathrm{~kg}$ were divided into four groups and fed a control diet or experimental diets enriched in 5\% linseed oil (LO), 2 $\mathrm{ppm} \mathrm{Se}$ (SE) or combined addition of 5\% LO and $2 \mathrm{ppm}$ Se (LOSE). All experimental diets statistically or numerically decreased the concentration of cis- $18: 1$ and saturated fatty acids in muscles and liver, while feeding Se usually significantly or numerically decreased the sum of all assayed fatty acids in muscles and liver. Diets enriched in Se and/or LO (SE and LOSE) significantly increased the Se level in these samples, as well as numerically increased the $\mathrm{Zn}$ content in muscles and liver. LO and LOSE significantly or numerically decreased $\Delta 9$ desaturation in muscles, liver and fat. LOSE numerically decreased the content of conjugated linoleic acid isomers in all assayed samples.
\end{abstract}

KEY WORDS: linseed oil, selenium, sheep, fatty acids, CLA, HPLC

\section{INTRODUCTION}

Increasing the polyunsaturated fatty acid (PUFA) content and modifying the fatty acid (FA) profile of food derived from ruminants, without lowering their organoleptic quality, is an effective way of helping humans to meet nutritional guidelines recommending elevating PUFA consumption (Demirel et al., 2004). Another potential route of obtaining high quality foods is to increase the content of essential elements in products originating from ruminants. Therefore, the main

\footnotetext{
"Supported in part by the State Committee for Scientific Research, Grant No. 3 PO6L 03422

${ }^{3}$ Corresponding author: e-mail: m.czauderna@ifzz.pan.pl
} 
objectives of the present trial were to determine whether supplementing diets of lambs with $2 \mathrm{ppm} \mathrm{Se}$ (as $\mathrm{Na}_{2} \mathrm{SeO}_{4}$ ) and $5 \%$ linseed oil (LO) (as a precursor of FAs containing conjugated double bonds (CFA)) changed the FA profile and altered the content of $\mathrm{Se}, \mathrm{Zn}, \mathrm{Fe}, \mathrm{Mg}$ and $\mathrm{Ca}$ in $M$. biceps femoris, intermuscular fat and liver.

\section{MATERIAL AND METHODS}

Twenty male Polish Merino lambs with an average body weight (BW) of $25 \pm 2 \mathrm{~kg}$ at the beginning of the experiment were individually housed. Fach group comprised 5 lambs. During a 1 -week preliminary period the animals were given ad libitum access to the standard concentrate-hay diet. Then, for 35 days the sheep ( 5 animals) were fed the standard concentrate-hay diet (Control) or experimental diets enriched in 5\% linseed oil (LO), $2 \mathrm{ppm} \mathrm{Se}$ (SE) or the experimental diet with the combined addition of $5 \% \mathrm{LO}$ and $2 \mathrm{ppm} \mathrm{Se}$ (LOSE). The rations were adjusted weekly to ensure ad lihitum access to feed. All of the chemicals used, the method of hydrolysis, derivatization, Waters HPLC equipment (US $\wedge$ ), were described previously (Czauderna et al., 2002, 2004). Underivatized conjugated linoleic acid (CL $\Lambda$ ) isomers and other fatty acids containing conjugated double bonds (CFA) were determined according to Czauderna et al. (2003), whilc all derivatized F $\Lambda$ were determined according to Czauderna and Kowalczyk (2002). Se, $\mathrm{Zn}, \mathrm{Fe}, \mathrm{Mg}$ and $\mathrm{Ca}$ in the assayed samples were determined by the CPI-MS method (Czauderna et al., 2004). Statistical analyses of the effect of LO or SE treatments were conducted using the nonparametric Mann-Whitncy $U$ test, while statistical analyses of the simultaneous $\mathrm{SE}$ and $\mathrm{LO}$ treatment were performed applying two-lactorial analysis. The Statistica (version 6) and Excel 2000 programs were used.

\section{RESULTS AND DISCUSSION}

The effects of administrating Se and/or LO on the fatty acid composition of M. biceps femoris, intermuscular fat and liver after 35 days of feeding Se and/or LO are summarized in Table 1. Feeding the diet enriched in LO or LOSE increased the content of CFA in lat and the PUFA level in the liver. All of the experimental diets statistically significantly or numerically decreased the concentration of cis-9C,18:1 and saturated fatty acids (SFA) in the assayed samples, while extra Se in the diet (SE) usually significantly or numerically decreased the sum of all assayed $F A s$ in $M$. biceps femoris and liver, as well as the SFA, MUFA and PUFA concentrations in the muscles and liver. Feeding the diet enriched with LO and Se (LOSE) numerically decreased the content of CLA isomers in all assayed samples. LO and LOSE significantly or numcrically decreased $\Delta 9$ desaturation in muscles, liver and fat. The SE and LOSE treatments increased the Se level in muscles and liver, while numerically elevated the $\mathrm{Zn}$ content in these samples. 
TABLE 1

Effects of diets on the content of selected FAs, elements, and on the weigth' of liver, muscle and fat of shecp

\begin{tabular}{|c|c|c|c|c|c|c|c|c|}
\hline \multirow[t]{2}{*}{ Item } & \multicolumn{5}{|c|}{ Group } & \multicolumn{3}{|c|}{$\begin{array}{c}\text { Significance of } \\
\text { effect }^{2}\end{array}$} \\
\hline & Control & LO & $\mathrm{SE}$ & IOSE & $\mathrm{SD}$ & $\mathrm{LO}$ & SE & LOSE \\
\hline M. biceps femoris, $\mathrm{kg}$ & & & & & & NS & NS & * \\
\hline $\mathrm{CLA}, \mu \mathrm{g} / \mathrm{g}$ & 357 & 307 & 178 & 305 & 76 & NS & $*$ & NS \\
\hline $\mathrm{CFA}^{3}, \mu \mathrm{g} / \mathrm{g}$ & 116 & 73 & 92 & 157 & 36 & NS & NS & NS \\
\hline cis-9C18:1, mg/g & 3.05 & 2.11 & 2.29 & 1.88 & 0.87 & NS & NS & $*$ \\
\hline$c i s$-MUFA, mg/g & 5.86 & 5.93 & 3.20 & 7.00 & 1.62 & NS & $* *$ & NS \\
\hline MUFA. $\mathrm{mg} / \mathrm{g}$ & 5.98 & 6.01 & 3.27 & 7.12 & 1.64 & NS & $* *$ & NS \\
\hline Sum of $F A s, \mathrm{mg} / \mathrm{g}$ & 11.12 & 10.52 & 6.87 & 12.75 & 2.48 & NS & * & NS \\
\hline PUFA, $\mathrm{mg} / \mathrm{g}$ & 8.02 & 8.26 & 4.82 & 9.88 & 2.12 & NS & * & NS \\
\hline $\mathrm{SFA}^{4}, \mathrm{mg} / \mathrm{g}$ & 3.10 & 2.27 & 2.05 & 2.87 & 0.50 & * & $*$ & NS \\
\hline$\Delta 9$ desaturase index & 0.730 & 0.666 & 0.711 & 0.683 & 0.028 & ** & NS & $* *$ \\
\hline $\mathrm{Se}, \mu \mathrm{g} / \mathrm{g}$ & 0.19 & 0.17 & 0.36 & 0.40 & 0.11 & NS & $* *$ & ** \\
\hline $\mathrm{Zn}, \mu \mathrm{g} / \mathrm{g}$ & 72 & 68 & 81 & 80 & 10 & NS & NS & NS \\
\hline $\mathrm{Fe}, \mu \mathrm{g} / \mathrm{g}$ & 61 & 60 & 72 & 63 & 12 & NS & NS & NS \\
\hline $\mathrm{Mg}, \mathrm{mg} / \mathrm{g}$ & 1.21 & 1.24 & 1.34 & 1.30 & 0.09 & NS & $*$ & NS \\
\hline $\mathrm{Ca}, \mu \mathrm{g} / \mathrm{g}$ & 242 & 262 & 257 & 293 & 40 & NS & NS & NS \\
\hline Liver, $\mathrm{g}$ & 618 & 625 & 563 & 659 & 54 & NS & NS & NS \\
\hline $\mathrm{CLA}, \mathrm{mg} / \mathrm{g}$ & 1.04 & 1.57 & 1.73 & 0.92 & 0.77 & NS & NS & NS \\
\hline $\mathrm{CFA}, \mathrm{mg} / \mathrm{g}$ & 2.40 & 2.36 & 0.85 & 2.13 & 1.61 & $\mathrm{NS}$ & $*$ & NS \\
\hline cis-9C18:1, mg/g & 6.12 & 4.25 & 5.70 & 4.15 & 1.44 & $\mathrm{NS}$ & NS & NS \\
\hline$c i s$-MUFA, mg/g & 21.8 & 48.8 & 19.1 & 35.8 & 14.4 & $* *$ & NS & NS \\
\hline MUFA, mg/g & 22.2 & 49.3 & 19.6 & 36.2 & 14.4 & $* *$ & NS & NS \\
\hline Sum of FAs, $\mathrm{mg} / \mathrm{g}$ & 41.9 & 65.7 & 37.5 & 50.6 & 14.6 & $* *$ & NS & NS \\
\hline PUFA, $\mathrm{mg} / \mathrm{g}$ & 29.4 & 57.4 & 26.4 & 43.9 & 15.2 & $* *$ & NS & $* *$ \\
\hline $\mathrm{SFA}, \mathrm{mg} / \mathrm{g}$ & 12.5 & 8.3 & 11.1 & 6.7 & 3.7 & $\mathrm{NS}$ & NS & * \\
\hline$\Delta 9$ desaturase index ${ }^{5}$ & 0.924 & 0.847 & 1.042 & 1.083 & 0.106 & NS & NS & NS \\
\hline $\mathrm{Se}, \mu \mathrm{g} / \mathrm{g}$ & 0.53 & 0.41 & 4.92 & 4.43 & 2.32 & NS & $* *$ & $* *$ \\
\hline $\mathrm{Zn}, \mu \mathrm{g} / \mathrm{g}$ & 66 & 61 & 79 & 77 & 11 & NS & NS & NS \\
\hline $\mathrm{Fe}, \mu \mathrm{g} / \mathrm{g}$ & 131 & 204 & 179 & 73 & 61 & $*$ & * & * \\
\hline $\mathrm{Mg}, \mathrm{mg} / \mathrm{g}$ & 745 & 744 & 875 & 846 & 93 & NS & NS & * \\
\hline $\mathrm{Ca}, \mu \mathrm{g} / \mathrm{g}$ & 181 & 178 & 214 & 210 & 55 & NS & NS & NS \\
\hline Intermuscular fat" & & & & & & & & \\
\hline CLA, mg/g & 4.56 & 2.45 & 4.55 & 3.48 & 2.02 & * & $\mathrm{NS}$ & NS \\
\hline $\mathrm{CFA}, \mathrm{mg} / \mathrm{g}$ & 0.117 & 0.534 & 0.183 & 0.625 & 0.286 & $* *$ & NS & $* *$ \\
\hline$c i s-9 \mathrm{C} 18: 1, \mathrm{mg} / \mathrm{g}$ & 27.2 & 12.2 & 34.2 & 19.8 & 13.3 & $* *$ & NS & NS \\
\hline cis-MUFA. mg/g & 72.4 & 60.2 & 75.9 & 71.8 & 26.5 & NS & NS & NS \\
\hline MUFA, $\mathrm{mg} / \mathrm{g}$ & 74.6 & 60.9 & 77.6 & 72.7 & 26.0 & NS & NS & NS \\
\hline sum of $\mathrm{FAs}, \mathrm{mg} / \mathrm{g}$ & 110 & 82 & 112 & 101 & 26.0 & NS & NS & VS \\
\hline PUFA, mg/g & 85.0 & 68.6 & 88.4 & 84.0 & 31.0 & NS & NS & NS \\
\hline $\mathrm{SFA}, \mathrm{mg} / \mathrm{g}$ & 25.2 & 13.9 & 23.4 & 17.2 & 7.1 & $* *$ & NS & $* *$ \\
\hline$\Delta 9$ desaturase index ${ }^{5}$ & 0.745 & 0.682 & 0.797 & 0.739 & 0.047 & NS & NS & VS \\
\hline
\end{tabular}

${ }^{1}$ weight derived from fresh organs and fresh muscle tissues

2 significance of effects: $* *$ - $\mathrm{P}<0.01 ;{ }^{*}-\mathrm{P}<0.05 ; \mathrm{NS}-\mathrm{P} \geq 0.05 ; \mathrm{SD}$ - pooled standard deviation

"non-CLA conjugated fatty acids (e.g.: C18:3, (20:3 and C20:4, see ref. Czauderna el al., 2004)

${ }^{4} \mathrm{SF} \wedge$ - saturated fatty acids (from $\mathrm{C} 8: 0$ to $\mathrm{C} 22: 0$ )

${ }^{5}$ concentration ratio: cis- $9 \mathrm{C} 18: 1 /(\mathrm{C} 18: 0+c i s-9 \mathrm{C} 18: 1)$

${ }^{6} \mathrm{Se}$ - below the limit of quantification 


\section{CONCLUSIONS}

Adding LO and/or Se to the diet for 35 days improved the nutritional quality of $M$. biceps femoris, intermuscular fat and liver by decreasing the concentration of saturated fatty acids. In particular, feeding LO with Se (LOSE) improved the nutritional value of products derived from sheep since this diet significantly elevated the content of MUFA, PUFA, $\mathrm{Zn}$ and Se (an essential element) in the meat and liver of sheep. Unfortunately, the LOSE treatment decreased the level of CLA isomers in all examined samples.

\section{REFERENCES}

Demirel G., Wachira A.M., Sinclair L.A., Wilkinson R.G., Wood J.D., Enser M., 2004. Effects of dietary $n-3$ polyunsaturated fatty acids, breed and dietary vitamin $E$ on the fatty acids of lamb muscle, liver and adipose tissue. Brit. J. Nutr. 91, 551-565

Czauderna M., Kowalczyk J., 2002. HPLC separation of some unsaturated and saturated fatty acids. Chem. Anal. (Warsaw) 47, 867-882

Czauderna M., Kowalczyk J., Wąsowska I., Niedźwiedzka K.M., 2002. A highly efficient method for derivatization of fatty acids for high performance liquid chromatography. J. Anim. Feed Sci. $11,517-526$

Czauderna M., Kowaiczyk J., Wąsowska I., Niedźwiedzka K.M., 2003. Determination of conjugated linoleic acid isomers by liquid chromatography and photodiode array detection. J. Anim. Feed Sci. $12,269-382$

Czauderna M., Kowalczyk J., Niedźwiedzka K.M., Wąsowska I., Pastuszewska B., Bulska E., Ruszczyńska A., 2004. Liver and body mass gain, content of conjugated linoleic acid (CLA) isomers and other fatty acids in the liver of rats fed CLA isomers and selenium. J. Anim. Feed Sci. $13,353-369$

\section{STRESZCZENIE}

Wplyw oleju Inianego i selenu na sklad kwasów tłuszczowych oraz zawartość pierwiastków w wybranych tkankach i wątrobie owiec

Badano wplyw dodatku oleju Inianego (LO) i/lub $\mathrm{Se}$ w postaci $\mathrm{Na}_{2} \mathrm{SeO}$, na masę wątroby, mięśnia udowego oraz. stężenie wybranych kwasów tłuszczowych i pierwiastków w tłuszcz.u śódmięśniowym, wątrobie oraz mięśniu udowym owiec. Diety z dodatkiem LO lub/i Se zmniejszają stężenic cis-9C18:1 oraz nasyconych kwasów thuszczowych w mięśniach i wątrobie, natomiast dodatek Se spowodował zmniejszanie zawartości sumy kwasów tłuszczowych w mięśniach i wątrobie. Skarmianie diet $z$ dodatkiem Se stymulowało gromadzenie Se ora $\mathrm{Zn} w$ mięśniach i wątrobie. Diety $z$ dodatkiem LO, bez względu na obecność Se, zmniejszają wydajność $\Delta$ 9-desaturacji w miçśniach oraz thuszczu śródmięśniowym. Diety z dodatkiem LO i Se (LOSE) liczbowo zmniejszają zawartość izomerów CLA we wszystkich badanych próbach. 